Dieses Dokument ist eine Zweitveröffentlichung (Verlagsversion) / This is a self-archiving document (published version):

Kurt Miller, Rudolf Morant, Arnulf Stenzl, Ivan Zuna, Manfred Wirth

A Phase II Study of the Central European Society of Anticancer-Drug Research (CESAR) Group: Results of an Open-Label Study of

Gemcitabine plus Cisplatin with or without Concomitant or Sequential Gefitinib in Patients with Advanced or Metastatic Transitional Cell Carcinoma of the Urothelium

Erstveröffentlichung in / First published in:

Urologia Internationalis. 2016, 96 (1), S. 5 - 13 [Zugriff am: 19.05.2020]. Karger. ISSN 14230399 .

DOI: https://doi.org/10.1159/000381589

Diese Version ist verfügbar / This version is available on:

https://nbn-resolving.org/urn:nbn:de:bsz:14-qucosa2-705898

„Dieser Beitrag ist mit Zustimmung des Rechteinhabers aufgrund einer (DFGgeförderten) Allianz- bzw. Nationallizenz frei zugänglich.“

This publication is openly accessible with the permission of the copyright owner. The permission is granted within a nationwide license, supported by the German Research Foundation (abbr. in German DFG).

www.nationallizenzen.de/ 


\title{
A Phase II Study of the Central European Society of Anticancer-Drug Research (CESAR) Group: Results of an Open-Label Study of Gemcitabine plus Cisplatin with or without Concomitant or Sequential Gefitinib in Patients with Advanced or Metastatic Transitional Cell Carcinoma of the Urothelium
}

\author{
Kurt Miller ${ }^{a}$ Rudolf Morant ${ }^{b} \quad$ Arnulf Stenzl $^{c} \quad$ Ivan Zuna $^{d}$ Manfred Wirth $^{\mathrm{e}}$

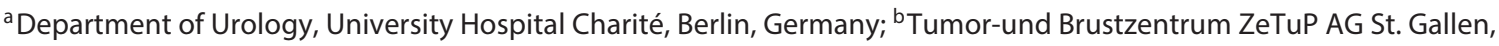 \\ St. Gallen, Switzerland; ' Department of Urology, Eberhard-Karls-University Tübingen, Tübingen, d Steinbachweg 37 , \\ Heidelberg, e'Department of Urology, Universität Dresden, Dresden, Germany
}

\author{
Key Words \\ Cisplatin · Gefitinib · Gemcitabine · Transitional cell \\ carcinoma $\cdot$ Urothelial carcinoma
}

\begin{abstract}
Introduction: This phase II trial evaluated the efficacy and safety of the epidermal growth factor receptor (EGFR) tyrosine kinase inhibitor, gefitinib, in combination with first-line chemotherapy in advanced urothelial cancer. Methods: Chemotherapy-naïve patients with advanced or metastatic urothelial carcinoma were randomized 1:1:1 to receive six cycles of chemotherapy (gemcitabine 1,250 mg/m ${ }^{2}$ on days 1 and 8 , and cisplatin $70 \mathrm{mg} / \mathrm{m}^{2}$ on day 1 of every cycle) concomitantly with gefitinib $250 \mathrm{mg} /$ day (arm A); or with sequential gefitinib ( $\operatorname{arm} B$ ); or alone ( $\operatorname{arm} \mathrm{C}$ ). The primary endpoint was the time to progression (TTP). Results: A total of 105 patients received study treatment. Median TTP for arms A, B, and C were 6.1, 6.3, and 7.8 months, respectively. There were no significant differences between treatment arms for any outcomes measured. The most common ad-
\end{abstract}

E-Mail karger@karger.com

www.karger.com/uin

\section{KARGER}

verse events were nausea and vomiting. Conclusion: Gefitinib in combination with chemotherapy did not improve efficacy in advanced urothelial cancer.

c) 2015 S. Karger AG, Basel

\section{Introduction}

Urothelial carcinoma remains one of the leading causes of cancer mortality and morbidity in Europe [1] and the United States [2]. Approximately, 20-40\% of newly diagnosed patients present with, or go on to develop, invasive disease [3]. Outcomes in these patients are particularly poor, with five-year survival rates for patients presenting with regional or distant metastases of 35 and $5 \%$, respectively [2].

In other malignancy types, such as non-small cell lung cancer (NSCLC), breast cancer, colorectal cancer, gastrointestinal stromal tumor, and renal cell cancer, the use of targeted therapies has had a major impact in terms of improved outcomes. Over the past decade, drugs such as (c) 2015 S. Karger AG, Basel

0042-1138/15/0961-0005\$39.50/0 
sunitinib, sorafenib, bevacizumab, imatinib, gefitinib, cetuximab, and trastuzumab have contributed to an increased clinical benefit observed in patients with cancer [4-7]. However, for patients with advanced or metastatic urothelial cancer, there are no approved targeted therapies and chemotherapy remains the standard of care [8].

The epidermal growth factor receptor (EGFR) has been implicated in the progression of urothelial carcinoma [9], and thus can be considered a potential therapeutic target. Previous studies report EGFR expression in urothelial carcinoma being in the range of 27 to $91 \%$ [10-15]. Furthermore, EGFR status has been shown to be associated with invasive disease [10] and predictive of progression and survival $[12,13,16-18]$.

Gefitinib, a selective EGFR tyrosine kinase inhibitor (TKI), has shown activity in preclinical [19] and clinical [20] studies in urothelial carcinomas. In addition, the combination therapy of gefitinib with gemcitabine and cisplatin has shown activity in other tumors [21-23].

The current study was initiated to further investigate the efficacy and safety of concomitant or sequential gefitinib compared with standard chemotherapy alone in chemotherapy-naïve patients with advanced urothelial carcinoma.

\section{Patients and Methods}

\section{Patients}

Patients eligible for inclusion were $\geq 18$ years old, having received no previous chemotherapy or other systemic antitumor therapy, estimated creatinine clearance (COCKCROFT) $<60 \mathrm{ml} /$ min, with histologically or cytologically confirmed, measurable, advanced, or metastatic transitional cell carcinoma of the urothelium and a World Health Organization (WHO) performance status of 0 to 1 . The study was conducted from December 2003 to October 2008 in accordance with relevant local regulations, the International Conference on Harmonisation Guidelines for Good Clinical Practice, and the ethical principles laid down in the Declaration of Helsinki [24]. All patients provided written informed consent before any study-related procedures were performed.

\section{Study Objectives}

The primary objective of the study was to assess the activity of gefitinib $(250 \mathrm{mg})$ in patients with advanced or metastatic transitional cell carcinoma of the urothelium, administered once daily continuously in addition to standard chemotherapy or administered after completion of standard chemotherapy. This was measured by time to progression (TTP), based on Response Evaluation Criteria In Solid Tumors (RECIST) v1.0. Tumor response assessments were performed by each investigator.

The secondary objectives of the study included evaluating the overall response rate (ORR), time to treatment failure (TTF), overall survival (OS), disease control rate (DCR), and duration of re- sponse. The safety objective of the study was to measure the safety and tolerability for each treatment arm. Serious adverse events (AEs) were defined as an AE that resulted in death; was life-threatening; resulted in hospitalization; resulted in prolonged disability/ incapacity; or a congenital abnormality or birth defect. Patients who experienced progression or toxicity were followed up for survival until withdrawal of study medication of the last patient (study closure). Patients who withdrew were followed up every 12 weeks for survival information until death.

\section{Study Design}

This was a phase II, multicenter, open-label, randomized study of gemcitabine and cisplatin with or without concomitant or sequential gefitinib. Patients were randomized $(1: 1: 1)$ into one of three arms. Across all three arms, standard chemotherapy was administered in 21-day cycles consisting of gemcitabine 1,250 $\mathrm{mg} / \mathrm{m}^{2}$ on days 1 and 8 and cisplatin $70 \mathrm{mg} / \mathrm{m}^{2}$ on day 1 . Arm A received six cycles of gemcitabine and cisplatin plus concomitant gefitinib $250 \mathrm{mg}$ once daily, followed by gefitinib $250 \mathrm{mg}$ once daily as maintenance therapy until tumor progression. Arm B received six cycles of gemcitabine and cisplatin followed by gefitinib $250 \mathrm{mg}$ once daily until progression; and arm C received six cycles of gemcitabine and cisplatin followed by observation until progression.

An extension group, comprising patients in arm B and arm C who were unable to complete six cycles of chemotherapy either due to toxicity or objective disease progression, received gefitinib 250 mg once daily until further progression. Estimating the efficacy and safety profile of patients in the extension arm was a further exploratory endpoint.

\section{Statistical Analysis}

For the intent-to-treat (ITT) population, 102 patients (34 per treatment group) were required. Assuming a drop-out rate of approximately $20 \%$, the sample size had to be 125 patients. The sample size was determined based on the following assumptions: 7.4 months' TTP with gemcitabine and cisplatin alone [25], corresponding to an 18-month progression-free rate of $18.5 \%$ (exponential survival function); $30 \%$ maximum benefit of additional use of gefitinib (sequentially or concomitantly), resulting in a TTP of 9.6 months (27.3\% progression-free patients) in the best treatment arm. The goal was to have a probability of $75 \%$ of concluding that further evaluation of gefitinib plus gemcitabine and cisplatin on the improvement of TTP in patients with advanced or metastatic transitional cell carcinoma of the urothelium is warranted, based on the observed difference in the response rates between the treatment arms using a selection design with three arms [26].

Standard summary statistics were used to describe variables. ORRs and DCRs were summarized with proportions together with exact two-sided 95\% confidence intervals (CI). Durations (TTP, OS, and duration of response) were summarized using KaplanMeier methods. The log-rank test was used to assess the differences between treatment arms.

Efficacy endpoints were analyzed using the ITT population. Safety endpoints were analyzed using the all-subjects-treated (AST) population.

Due to the selection design of this study, the trial was noncomparative in the strong confirmatory statistical sense. The goal of the study was to select the most efficient of the three treatment arms, 


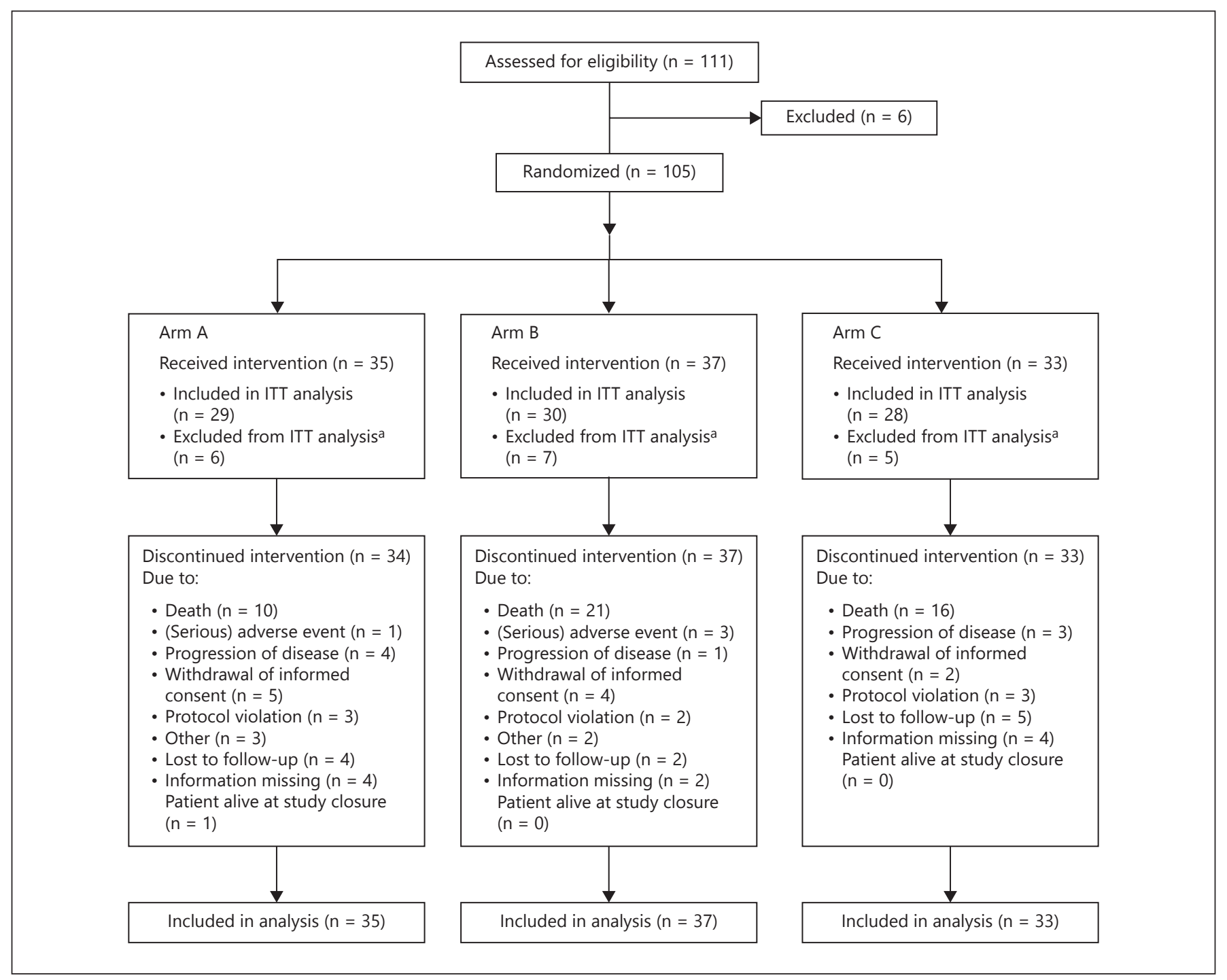

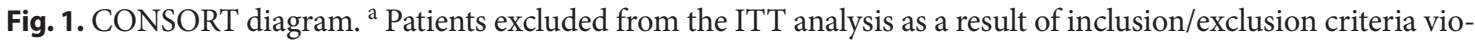
lation $(n=3)$ and missing tumor assessments $(n=15)$ - indeterminate across all three arms. ITT $=$ Intent-to-treat.

which would be used in a subsequent study. Despite the insufficient statistical power to assess trends in patient response to the study treatments, a log-rank test was performed for an exploratory comparison of all three target variables.

\section{Results}

\section{Study Population}

A total of 111 patients from 19 research sites in Germany and Switzerland were screened. Of these, 105 patients received study treatment (AST population). Eighteen of the 105 patients were excluded from the ITT population: three patients as a result of violation of the inclusion/exclusion criteria, and 15 patients as a consequence of missing their tumor assessment. Thus, a total of 87 patients were included in the ITT analysis (fig. 1).

Disease characteristics at baseline were representative of a population with histologically or cytologically confirmed, measurable, advanced, or metastatic transitional cell carcinoma of the urothelium. Two patients who had squamous cell histology were erroneously enrolled. The majority had metastatic disease (arm A 90\%, arm B 81\%, arm C $83 \%$ ), and a WHO performance status of 0 or 1 (table 1). Two patients who had a WHO performance status of 2 were incorrectly enrolled. 
Table 1. Baseline demographics and disease characteristics

\begin{tabular}{|c|c|c|c|}
\hline & \multicolumn{3}{|c|}{ Number of patients (\%) } \\
\hline & $\operatorname{arm} \mathrm{A}$ & $\operatorname{arm~B}$ & $\operatorname{arm} \mathrm{C}$ \\
\hline \multicolumn{4}{|l|}{ Population, n (\%) } \\
\hline All patients screened & $36(100.0)$ & $38(100.0)$ & $37(100.0)$ \\
\hline All patients treated & $35(97.2)$ & $37(97.4)$ & $33(89.2)$ \\
\hline Intent-to-treat & $29(80.6)$ & $30(78.9)$ & $28(75.7)$ \\
\hline \multicolumn{4}{|l|}{ Sex, n (\%) } \\
\hline Female & $12(34.3)$ & $12(32.4)$ & $7(21.2)$ \\
\hline Male & $23(65.7)$ & $24(64.9)$ & $26(78.8)$ \\
\hline Missing & 0 & $1(2.7)$ & 0 \\
\hline \multicolumn{4}{|l|}{ Age, years } \\
\hline Mean \pm SD & $61.8 \pm 11.3$ & $64.7 \pm 9.5$ & $61.4 \pm 9.7$ \\
\hline Median & 66 & 66 & 63 \\
\hline Range & $41-84$ & $45-80$ & $42-78$ \\
\hline \multicolumn{4}{|l|}{ Race, n (\%) } \\
\hline Caucasian & $35(100.0)$ & $37(100.0)$ & $33(100.0)$ \\
\hline \multicolumn{4}{|c|}{ WHO performance status } \\
\hline 0 & $20(58.8)$ & $17(45.9)$ & $19(59.4)$ \\
\hline 1 & $13(38.2)$ & $19(51.4)$ & $13(40.6)$ \\
\hline 2 & $1(2.9)$ & $1(2.7)$ & 0 \\
\hline Missing & $1(2.7)$ & $0(0.0)$ & $1(2.7)$ \\
\hline \multicolumn{4}{|l|}{ Histology, n (\%) } \\
\hline Transitional cell & $28(80.0)$ & $31(83.8)$ & $28(84.9)$ \\
\hline Squamous cell & 0 & $1(2.7)$ & $1(3.0)$ \\
\hline Adenoid & $2(5.7)$ & 0 & 0 \\
\hline Unknown & $4(11.4)$ & $4(10.8)$ & $2(6.1)$ \\
\hline Missing & $1(2.9)$ & $1(2.7)$ & $2(6.1)$ \\
\hline \multicolumn{4}{|l|}{$\begin{array}{l}\text { Any tumor-related } \\
\text { surgery }\end{array}$} \\
\hline Yes & $35(100.0)$ & $34(91.9)$ & $31(93.4)$ \\
\hline No & 0 & $3(8.1)$ & $1(3.0)$ \\
\hline Missing & 0 & 0 & $1(3.0)$ \\
\hline \multicolumn{4}{|c|}{ Any tumor-related radiotherapy } \\
\hline Yes & 0 & $3(8.1)$ & $1(3.0)$ \\
\hline No & $35(100.0)$ & $33(89.2)$ & $29(87.9)$ \\
\hline Missing & 0 & $1(2.7)$ & $3(9.1)$ \\
\hline
\end{tabular}

$\mathrm{SD}=$ Standard deviation $; \mathrm{WHO}=$ World Health Organization .

Patient demographics were generally consistent across the treatment arms; all patients were of Caucasian origin, and the majority were elderly males. Almost all patients had undergone prior surgery, with only four having received prior radiotherapy.

The most common surgery performed was transurethral resection of the bladder (41.7\%). Other operations included cystectomy, nephro-urectomy, prostatectomy, and laparotomy.

In total, 19 patients $(63.3 \%)$ received gefitinib in arm $B$ after completing six cycles of chemotherapy. The extension arm included only two patients (1.9\%), who were treated with gefitinib; the exploratory analysis was therefore not conducted due to the small sample size.

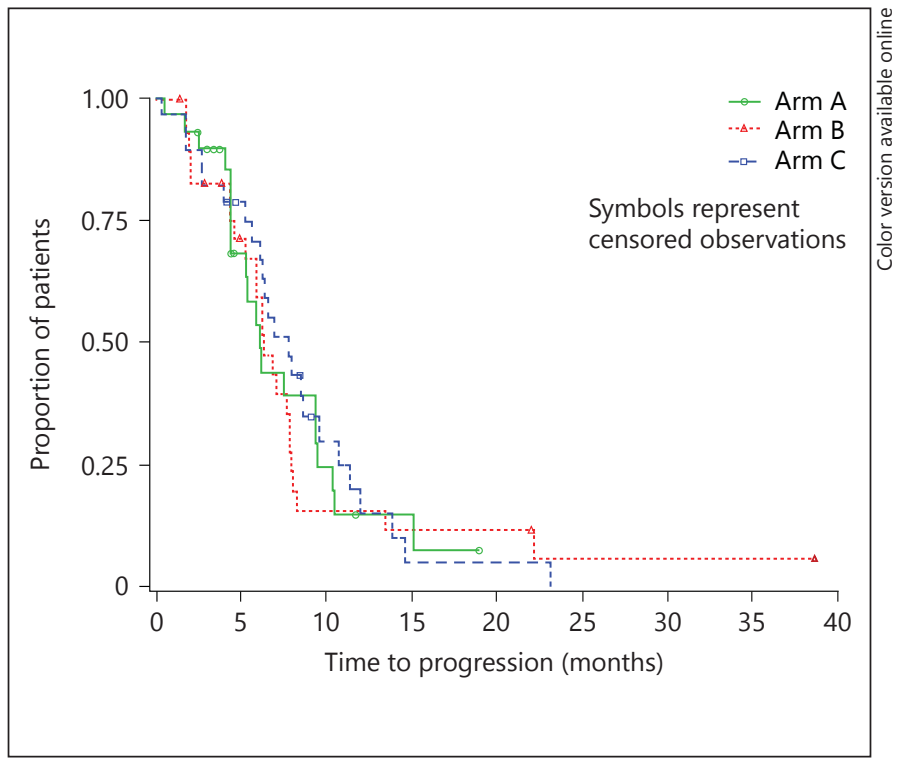

Fig. 2. Kaplan-Meier plot of time to progression.

Table 2. Response rates

\begin{tabular}{llll}
\hline \multirow{4}{*}{} & \multicolumn{2}{l}{ Number of patients $(\%)$} \\
\cline { 2 - 4 } & $\begin{array}{l}\text { arm A } \\
(\mathrm{n}=29)\end{array}$ & $\begin{array}{l}\text { arm B } \\
(\mathrm{n}=30)\end{array}$ & $\begin{array}{l}\operatorname{arm~C} \\
(\mathrm{n}=28)\end{array}$ \\
\hline ORR & $17(58.6)$ & $16(53.3)$ & $12(42.8)$ \\
PR & $15(51.7)$ & $15(50.0)$ & $10(35.7)$ \\
CR & $2(6.8)$ & $1(3.3)$ & $2(7.1)$ \\
SD & $12(42.8)$ & $10(35.7)$ & $8(28.5)$ \\
\hline
\end{tabular}

$\mathrm{CR}=$ Complete response; $\mathrm{ORR}=$ overall response rate; $\mathrm{PR}=$ partial response; $\mathrm{SD}=$ stable disease .

Efficacy Results

Median TTP for patients in arm A was 6.1 months (95\% CI 4.39-9.40), in arm B 6.3 months (95\% CI 5.247.80), and in arm C 7.8 months (95\% CI 6.19-9.63). An exploratory analysis indicated that there were no statistically significant differences between the treatment arms (fig. 2).

Similarly, there were no significant differences between the treatment arms for any of the secondary endpoints. Forty-five of the 87 patients treated with gefitinib had an objective tumor response, according to RECIST criteria, comprising 40 partial responders and five complete responders. The ORRs were $58.6,53.3$, and $42.8 \%$ in arms $\mathrm{A}, \mathrm{B}$, and $\mathrm{C}$, respectively (table 2 ). 


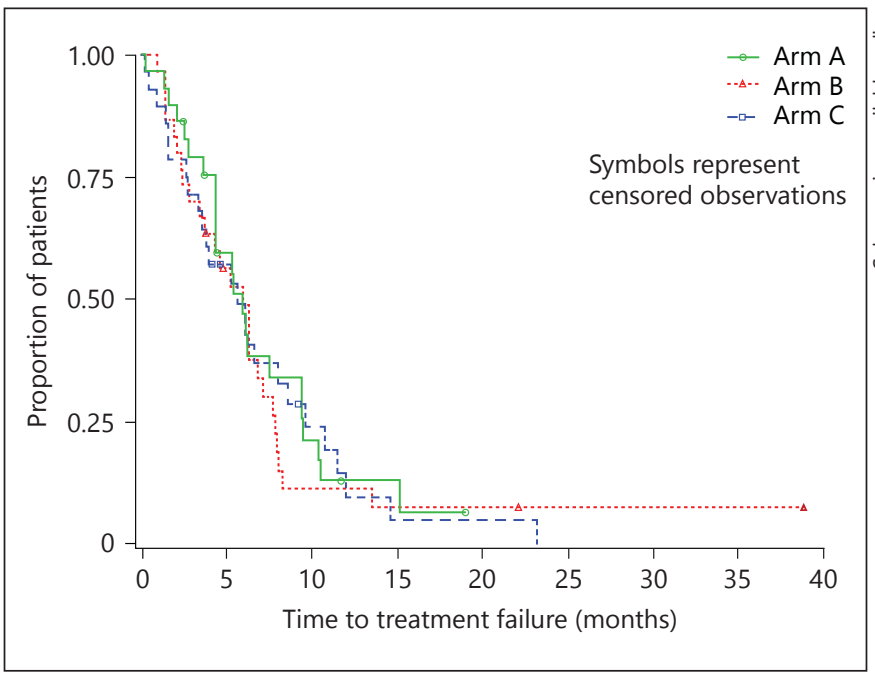

Fig. 3. Kaplan-Meier plot of time to treatment failure.

The median TTF for patients in arms A, B, and C was 5.9 months (95\% CI 4.36-9.37), 5.9 months (95\% CI 3.44-7.11), and 5.6 months (95\% CI 3.54-8.59), respectively (fig. 3). The median OS for patients in arm A was 13.3 months (95\% CI 10.49-19.24), in arm B 8.5 months (95\% CI 6.95-14.49), and in arm C 15.9 months (95\% CI 10.88-31.27) (fig. 4).

Measurements of target and non-target lesions as per RECIST were performed at regular intervals (every two cycles). However, the investigator's assessment of the overall response was not collected at each individual time point. A statement of the best response achieved during the study was collected at the end of the last chemotherapy visit. Thus, the DCR and duration of response were not assessed.

\section{Toxicity}

All patients treated in the study experienced at least one $\mathrm{AE}$, the most common events being nausea, vomiting, leukopenia, and fatigue. Most AEs were characterized by mild-to-moderate intensity (Common Toxicity Criteria (CTC) grades 1 and 2). There were 60 serious AEs reported in 105 patients (57.14\%, AST population), the most frequent being pancytopenia, pyrexia, and vomiting (table 3 ).

In arm A, there were 109 AEs considered gefitinibrelated, according to investigator assessment. Of these, rash (CTC grade 1 or 2 ) was the most common $(40.0 \%$ of patients). There were 13 gefitinib-related SAEs in arm A. In arm B, 23 AEs were considered by investigators as likely to be related to gefitinib, of which diarrhea (CTC grade 1 or 2 , except in one patient) was the most common

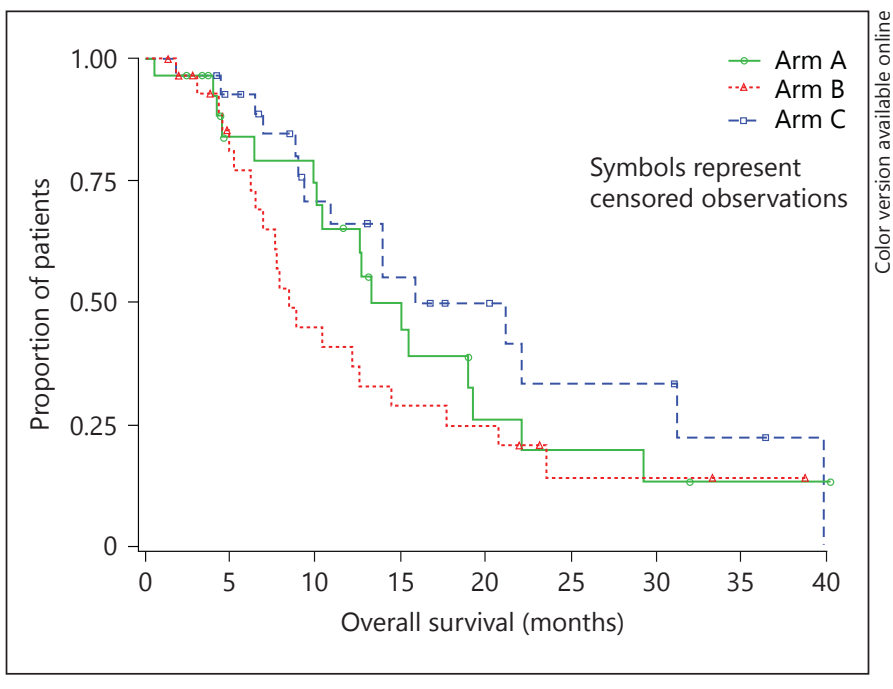

Fig. 4. Kaplan-Meier plot of overall survival.

(10.8\% of patients). There were two gefitinib-related SAEs in arm B.

Overall, there were 152 cases of therapy delay or dose reduction due to AEs across all arms of the study. There were 17 dose interruptions, most frequently due to toxicity. There were no dose interruptions in arm C. The most common reason for study discontinuation was death: 10 patients $(28.5 \%)$ in arm A; 21 patients $(56.8 \%)$ in arm $\mathrm{B}$; and 17 patients $(51.5 \%)$ in arm C. In total, there were 61 deaths during the course of the study: 19 (54.3\%), 23 (62.2\%), and 19 (57.6\%) in arms A, B, and C, respectively. The most common cause of death was urothelial carcinoma disease progression (17, 20, 19 in arms A, B, and C, respectively). Deaths not considered related to disease progression were caused by septic shock (one patient) and apoplexy (one patient) in arm A, and pulmonary insufficiency (one patient), cardiorespiratory failure (one patient), and unknown cause (one patient) in arm B.

\section{Discussion}

Cisplatin-based chemotherapy is the standard of care in patients with advanced urothelial carcinoma. Specifically, gemcitabine-cisplatin combination chemotherapy has been shown to provide the best efficacy and tolerability, replacing methotrexate, vinblastine, doxorubicin, and cisplatin as the treatment of choice [27]. Efforts to improve outcomes in this patient group have focused on the addition of a third drug. It has been proposed that the addition of a targeted therapeutic agent would result in im- 
Table 3. Adverse events and serious adverse events regardless of causality occurring in $>10 \%$ frequency in any arm

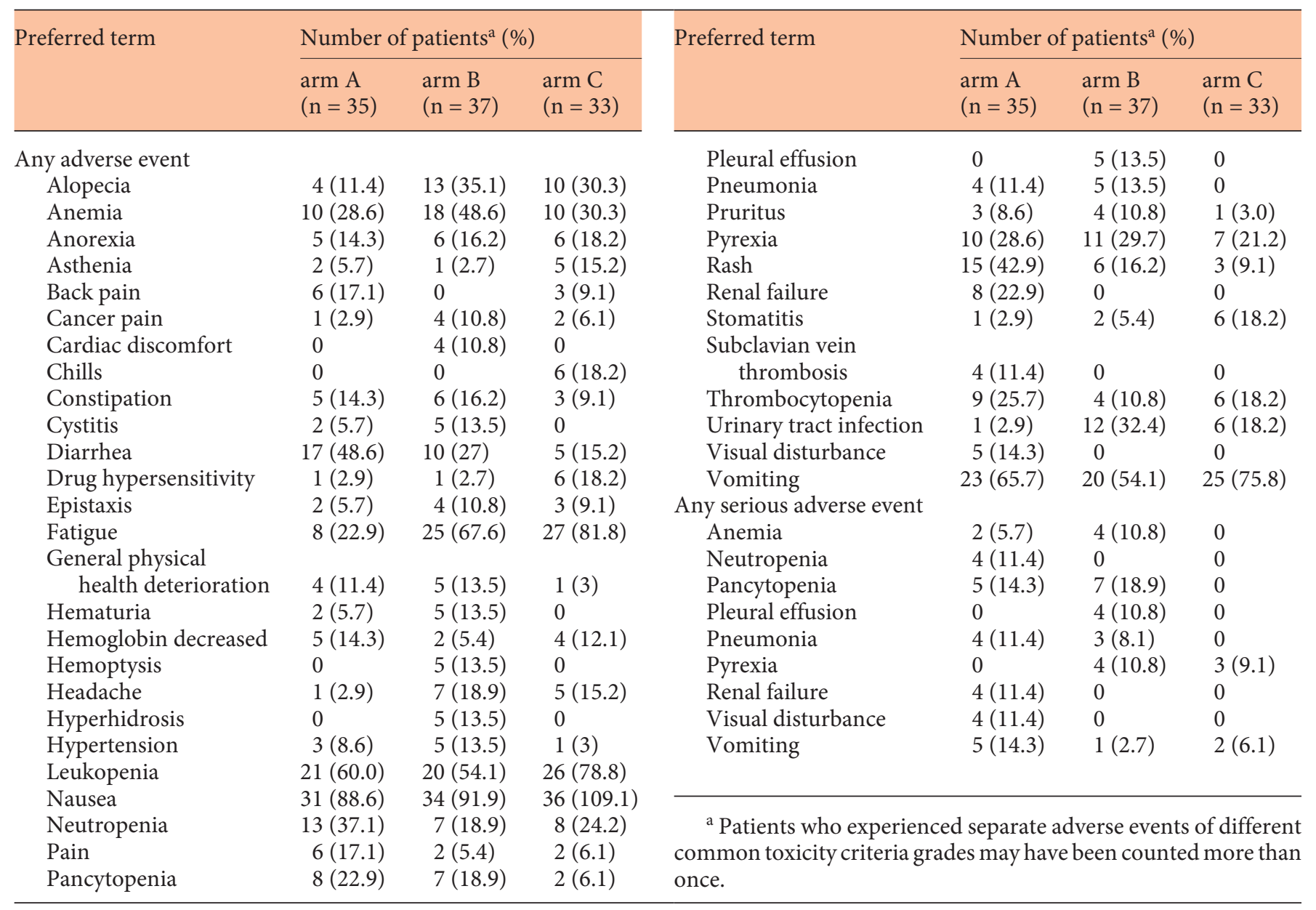

proved efficacy and minimal toxicity, as observed in other tumor types [4-7]. Presently, there are no approved targeted therapies for urothelial carcinoma; however, a number of potential molecular targets are being investigated in clinical research, including the EGFR family, multitargeted TKIs, angiogenesis (vascular endothelial growth factor (VEGF) and VEGFR), fibroblast growth factor receptor(FGFR), RTK-Ras/Raf/MAPK, PI3K/AKT/mTOR, and anti-CTLA4 antibody (reviewed in [28-30]).

The aim of the current study was to establish whether the efficacy of the gemcitabine-cisplatin regimen would be improved with the addition of the EGFR-TKI gefitinib. This combination and dosing (gefitinib $250 \mathrm{mg}$, gemcitabine $1,250 \mathrm{mg} / \mathrm{m}^{2}$ ) appeared to be highly active and well tolerated in a phase I study in patients with advanced solid tumors [21]. The gemcitabine dose of $1,250 \mathrm{mg} / \mathrm{m}^{2}$ has also been shown to be well tolerated in patients with transitional cell carcinoma of the bladder [31,32]. Our results did not show any significant benefits with either concomitant or sequential gefitinib, although a trend towards higher response rates was observed. In our study, the ORRs in both gefitinib arms (arms A and B) were similar to those reported in the gemcitabine-cisplatin only arm (49.4\%) in a phase III trial [33] and slightly higher than those reported in a phase II trial of gemcitabinecisplatin given concomitantly with gefitinib in patients with advanced urothelial carcinoma (58.6 and $53.3 \%$ vs. 42.6\%) [34]. Unintentional selection bias may account for the comparatively low response rates. It is probable that the OS data were influenced by the nature of subsequent treatments; however, information on these treatments was not collected, and this is therefore recognized as a limitation of the OS findings.

The toxicity profiles of both gefitinib arms (arms A and B) were similar to that observed for gemcitabine-cisplatin alone (arm C). All AEs were consistent with the 
tolerability profiles of the study drugs and the conditions associated with progression of urothelial carcinoma.

At the time this study was conducted, the role played by mutations in the EGFR gene in the response to gefitinib was not fully understood and EGFR mutation testing was not typically performed in urothelial carcinoma. Subsequently, studies in advanced NSCLC have demonstrated that certain somatic EGFR mutations predict for an improved tumor response to gefitinib treatment, compared with wild-type disease. Consequently, EGFR mutation testing is now part of routine investigations in advanced NSCLC $[35,36]$.

A possible explanation for the lack of efficacy observed in the gefitinib arms in comparison with the control arm in the current study could be due to the absence of EGFR mutations conferring sensitivity to EGFR-TKI; however, as retrospective testing is not possible, this cannot be verified. In addition, EGFR-TKI-sensitizing mutations in urothelial carcinoma are thought to be extremely rare - a number of studies investigating this tumor type have been unable to determine their existence [37-41]. Preclinical studies in urothelial carcinoma have found that the tumor cell-growth inhibition effect of gefitinib is independent of both the mutation status and protein level of EGFR [37, 42]. Inoue et al. also suggested that upregulation of YY1 and E-cadherin may be implicated in gefitinib-sensitivity observed in certain bladder cancer cell lines [42]. In addition, uncoupling of mitogenic pathways downstream of EGFR, due to PDGFR $\beta$ activation, has been shown to cause resistance to gefitinib in bladder cancer cell lines [43].

Targeting multiple pathways in order to improve treatment outcomes in advanced urothelial cancer has also been suggested. Several studies have proposed that co-expression patterns of EGFR alongside other members of the EGFR super-family or the tyrosine kinase recepteur d'origine nantais (RON) may be a better prognostic indicator than any of the receptors alone in urothelial carcinoma $[15,44,45]$. Hsu et al. have also presented clinical evidence that EGFR and RON are able to activate one another in bladder cancer cell lines [45]. Conflicting results have been reported for the VEGFR and EGFR dual inhibitor vandetanib. Greater antitumor activity was exhibited for vandetanib than gefitinib in human bladder cancer cell lines, and vandetanib also displayed synergism with cisplatin [39]. However, vandetanib in combination with docetaxel did not exhibit a significant improvement in progression-free survival in patients with advanced urothelial cancer [46].

Data indicate that radical treatment of the tumor, even in a metastatic setting, may improve outcomes [47], and it would be interesting to investigate whether there were differences in findings between the patients who received transurethral resection, radical cystectomy, and radiation alone. Unfortunately, this was not a planned outcome for this study and the data are not available; however, it is recommended that this analysis should be included in future trials of this nature.

In summary, gefitinib did not contribute to better patient outcomes in this population of metastatic urothelial carcinoma; platinum-based chemotherapy remains the cornerstone of treatment. However, it is hoped that by gaining a better understanding of the different molecular pathways that influence disease progression in this tumor indication, more effective targeted therapies may be developed. An assessment of EGFR status would be of potential value in future studies of EGFR/TKIs in urothelial carcinoma; identification of patients that is most likely to benefit from these therapies may also result in improved clinical outcomes.

\section{Acknowledgments}

Medical writing services were provided by Tom Westgate and Kerrie O'Rourke of iMed Comms, Macclesfield, UK, and were funded by AstraZeneca AG, Germany.

\section{Disclosure Statement}

The study was funded by AstraZeneca. Kurt Miller has received consultancy fees from Amgen, AstraZeneca, Bayer, BMS, Dendreon, Ferring, GSK, Janssen-Cilag, Merck, Novartis, Pfizer, and Roche, and institutional grants from Novartis. Rudolf Morant has received consultancy fees for a one-off training session (not related to this manuscript). Manfred Wirth has received consultancy fees from Bayer, Dendreon, Janssen-Cilag, Merck, and Takeda Oncology Company - Millennium Pharmaceuticals, and payment for lectures/speakers' bureaus from Janssen-Cilag, Orion Pharma, and Pfizer. Ivan Zuna and Arnulf Stenzl have declared no conflicts of interest.
References
1 Ferlay J, Randi G, Bosetti C, Levi F, Negri E, Boyle P, La Vecchia C: Declining mortality from bladder cancer in Europe. BJU Int 2008; 101:11-19.
-2 Siegel R, Naishadham D, Jemal A: Cancer sta- tistics, 2012. CA Cancer J Clin 2012;62:10-29.
-3 Stein JP, Lieskovsky G, Cote R, Groshen S, Feng AC, Boyd S, Skinner E, Bochner B, Thangathurai D, Mikhail M, Raghavan D, Skinner DG: Radical cystectomy in the treat- ment of invasive bladder cancer: long-term results in 1,054 patients. J Clin Oncol 2001;19: 666-675. 
4 Ross JS, Schenkein DP, Pietrusko R, Rolfe M, Linette GP, Stec J, Stagliano NE, Ginsburg GS, Symmans WF, Pusztai L, Hortobagyi GN: Targeted therapies for cancer 2004. Am J Clin Pathol 2004;122:598-609.

5 Petrelli NJ, Winer EP, Brahmer J, Dubey S, Smith S, Thomas C, Vahdat LT, Obel J, Vogelzang N, Markman M, Sweetenham JW, Pfister D, Kris MG, Schuchter LM, Sawaya R, Raghavan D, Ganz PA, Kramer B: Clinical cancer advances 2009: major research advances in cancer treatment, prevention, and screening - a report from the American society of clinical oncology. J Clin Oncol 2009;27: 6052-6069.

-6 Petrelli A, Giordano S: From single- to multitarget drugs in cancer therapy: when aspecificity becomes an advantage. Curr Med Chem 2008; $15: 422-432$.

7 Dreyer C, Raymond E, Faivre S: [Targeted therapies and their indications in solid neoplasias]. Rev Med Interne 2009;30:416-424.

-8 Stenzl A, Cowan NC, De Santis M, Kuczyk MA, Merseburger AS, Ribal MJ, Sherif A, Witjes JA: Treatment of muscle-invasive and metastatic bladder cancer: update of the EAU guidelines. Eur Urol 2011;59:1009-1018.

-9 Gallucci M, Merola R, Leonardo C, Ruggeri EM, Cianciulli AM: Analysis of HER2 expression in primary urinary bladder carcinoma and corresponding metastases. BJU Int 2005; 96:440; author reply 440-441.

10 Wright C, Mellon K, Johnston P, Lane DP, Harris AL, Horne CH, Neal DE: Expression of mutant p53,c-erbB-2 and the epidermal growth factor receptor in transitional cell carcinoma of the human urinary bladder. $\mathrm{Br} \mathrm{J}$ Cancer 1991;63:967-970.

11 Wang X, Zhang S, MacLennan GT, Eble JN, Lopez-Beltran A, Yang XJ, Pan CX, Zhou H, Montironi R, Cheng L: Epidermal growth factor receptor protein expression and gene amplification in small cell carcinoma of the urinary bladder. Clin Cancer Res 2007;13:953957.

12 Lipponen P, Eskelinen M: Expression of epidermal growth factor receptor in bladder cancer as related to established prognostic factors, oncoprotein (c-erbB-2, p53) expression and long-term prognosis. Br J Cancer 1994; 69:1120-1125.

-13 Khaled HM, Bahnassy AA, Raafat AA, Zekri AR, Madboul MS, Mokhtar NM: Clinical significance of altered nm23-H1, EGFR, RB and p53 expression in bilharzial bladder cancer. BMC Cancer 2009;9:32.

14 Guo CC, Fine SW, Epstein JI: Noninvasive squamous lesions in the urinary bladder: a clinicopathologic analysis of 29 cases. Am J Surg Pathol 2006;30:883-891.

15 Chow NH, Chan SH, Tzai TS, Ho CL, Liu HS: Expression profiles of ErbB family receptors and prognosis in primary transitional cell carcinoma of the urinary bladder. Clin Cancer Res 2001;7:1957-1962.

16 Mellon K, Wright C, Kelly P, Horne CH, Neal DE: Long-term outcome related to epidermal growth factor receptor status in bladder cancer. J Urol 1995;153:919-925.

17 Kramer C, Klasmeyer K, Bojar H, Schulz WA, Ackermann R, Grimm MO: Heparin-binding epidermal growth factor-like growth factor isoforms and epidermal growth factor receptor/ErbB1 expression in bladder cancer and their relation to clinical outcome. Cancer 2007;109:2016-2024.

18 Chow NH, Liu HS, Lee EI, Chang CJ, Chan SH, Cheng HL, Tzai TS, Lin JS: Significance of urinary epidermal growth factor and its receptor expression in human bladder cancer. Anticancer Res 1997;17:1293-1296.

19 Nutt JE, Foster PA, Mellon JK, Lunec J: hEGR1 is induced by EGF, inhibited by gefitinib in bladder cell lines and related to EGF receptor levels in bladder tumours. Br J Cancer 2007;96:762-768.

20 Petrylak DP, Tangen CM, Van Veldhuizen PJ Jr, Goodwin JW, Twardowski PW, Atkins JN, Kakhil SR, Lange MK, Mansukhani M, Crawford ED: Results of the Southwest oncology group phase II evaluation (study S0031) of ZD1839 for advanced transitional cell carcinoma of the urothelium. BJU Int 2010;105: 317-321.

21 Giaccone G, Gonzalez-Larriba JL, van Oosterom AT, Alfonso R, Smit EF, Martens M, Peters GJ, van der Vijgh WJ, Smith R, Averbuch S, Fandi A: Combination therapy with gefitinib, an epidermal growth factor receptor tyrosine kinase inhibitor, gemcitabine and cisplatin in patients with advanced solid tumors. Ann Oncol 2004;15:831-838.

22 Giaccone G, Herbst RS, Manegold C, Scagliotti G, Rosell R, Miller V, Natale RB, Schiller JH, Von Pawel J, Pluzanska A, Gatzemeier U, Grous J, Ochs JS, Averbuch SD, Wolf MK, Rennie P, Fandi A, Johnson DH: Gefitinib in combination with gemcitabine and cisplatin in advanced non-small-cell lung cancer: a phase III trial - INTACT 1. J Clin Oncol 2004; 22:777-784.

23 Sirotnak FM, Zakowski MF, Miller VA, Scher HI, Kris MG: Efficacy of cytotoxic agents against human tumor xenografts is markedly enhanced by coadministration of ZD1839 (Iressa), an inhibitor of EGFR tyrosine kinase. Clin Cancer Res 2000;6:48854892.

24 World Medical Association: WMA Declaration of Helsinki - Ethical Principles for Medical Research Involving Human Subjects, 2008. http://www.wma.net/en/30publications/ 10policies/b3/ (accessed May 7, 2013).

25 von der Maase H, Hansen SW, Roberts JT, Dogliotti L, Oliver T, Moore MJ, Bodrogi I, Albers P, Knuth A, Lippert CM, Kerbrat P, Sanchez Rovira P, Wersall P, Cleall SP, Roychowdhury DF, Tomlin I, Visseren-Grul CM, Conte PF: Gemcitabine and cisplatin versus methotrexate, vinblastine, doxorubicin, and cisplatin in advanced or metastatic bladder cancer: results of a large, randomized, multinational, multicenter, phase III study. J Clin Oncol 2000;18:3068-3077.
26 Sargent DJ, Goldberg RM: A flexible design for multiple armed screening trials. Stat Med 2001;20:1051-1060.

27 Rosenberg JE, Carroll PR, Small EJ: Update on chemotherapy for advanced bladder cancer. J Urol 2005; 174:14-20.

28 Wallerand H, Bernhard JC, Culine S, Ballanger P, Robert G, Reiter RE, Ferriere JM, Ravaud A: Targeted therapies in non-muscleinvasive bladder cancer according to the signaling pathways. Urol Oncol 2011;29:4-11.

-29 Serrano C, Morales R, Suárez C, Núñez I, Valverde C, Rodón J, Humbert J, Padrós O, Carles J: Emerging therapies for urothelial cancer. Cancer Treat Rev 2012;38:311-317.

30 Pezaro C, Liew MS, Davis ID: Urothelial cancers: using biology to improve outcomes. Expert Rev Anticancer Ther 2012;12:87-98.

- 31 Dogliotti L, Carteni G, Siena S, Bertetto O, Martoni A, Bono A, Amadori D, Onat H, Marini L: Gemcitabine plus cisplatin versus gemcitabine plus carboplatin as first-line chemotherapy in advanced transitional cell carcinoma of the urothelium: results of a randomized phase 2 trial. Eur Urol 2007;52:134141.

-32 Mallick JA, Ali SA, Siddiqui N, Fareed A: Impact of gemcitabine and cisplatin with radiotherapy in locally advanced or metastatic transitional cell carcinoma of urinary bladder. J Pak Med Assoc 2003;53:547-552.

-33 von der Maase H, Sengelov L, Roberts JT, Ricci S, Dogliotti L, Oliver T, Moore MJ, Zimmermann A, Arning M: Long-term survival results of a randomized trial comparing gemcitabine plus cisplatin, with methotrexate, vinblastine, doxorubicin, plus cisplatin in patients with bladder cancer. J Clin Oncol 2005: 23:4602-4608.

34 Philips GK, Halabi S, Sanford BL, Bajorin D, Small EJ: A phase II trial of cisplatin (C), gemcitabine $(\mathrm{G})$ and gefitinib for advanced urothelial tract carcinoma: results of cancer and leukemia group B (CALGB) 90102. Ann Oncol 2009;20:1074-1079.

35 Lynch TJ, Bell DW, Sordella R, Gurubhagavatula $S$, Okimoto RA, Brannigan BW, Harris PL, Haserlat SM, Supko JG, Haluska FG, Louis DN, Christiani DC, Settleman J, Haber DA: Activating mutations in the epidermal growth factor receptor underlying responsiveness of non-small-cell lung cancer to gefitinib. N Engl J Med 2004;350:2129-2139.

36 Mok TS, Wu YL, Thongprasert S, Yang CH, Chu DT, Saijo N, Sunpaweravong P, Han B, Margono B, Ichinose Y, Nishiwaki Y, Ohe Y, Yang JJ, Chewaskulyong B, Jiang H, Duffield EL, Watkins CL, Armour AA, Fukuoka M: Gefitinib or carboplatin-paclitaxel in pulmonary adenocarcinoma. N Engl J Med 2009; 361:947-957.

37 Yang JL, Qu XJ, Hayes VM, Brenner PC, Russell PJ, Goldstein D: Erlotinib (OSI-774)induced inhibition of transitional cell carcinoma of bladder cell line growth is enhanced by interferon-alpha. BJU Int 2007;99:15391545. 
38 Villares GJ, Zigler M, Blehm K, Bogdan C, McConkey D, Colin D, Bar-Eli M: Targeting EGFR in bladder cancer. World J Urol 2007; 25:573-579.

- 39 Flaig TW, Su LJ, McCoach C, Li Y, Raben D, Varella-Garcia M, Bemis LT: Dual epidermal growth factor receptor and vascular endothelial growth factor receptor inhibition with vandetanib sensitizes bladder cancer cells to cisplatin in a dose- and sequence-dependent manner. BJU Int 2009;103:1729-1737.

40 Chaux A, Cohen JS, Schultz L, Albadine R, Jadallah S, Murphy KM, Sharma R, Schoenberg MP, Netto GJ: High epidermal growth factor receptor immunohistochemical expression in urothelial carcinoma of the bladder is not associated with EGFR mutations in exons 19 and 21: a study using formalin-fixed, paraffin-embedded archival tissues. Hum Pathol 2012;43:1590-1595.

41 Blehm KN, Spiess PE, Bondaruk JE, Dujka ME, Villares GJ, Zhao YJ, Bogler O, Aldape
KD, Grossman HB, Adam L, McConkey DJ, Czerniak BA, Dinney CP, Bar-Eli M: Mutations within the kinase domain and truncations of the epidermal growth factor receptor are rare events in bladder cancer: implications for therapy. Clin Cancer Res 2006;12:46714677.

42 Inoue R, Matsuyama H, Yano S, Yamamoto Y, Iizuka N, Naito K: Gefitinib-related gene signature in bladder cancer cells identified by a cDNA microarray. Anticancer Res 2006;26: 4195-4202.

43 Kassouf W, Dinney CP, Brown G, McConkey DJ, Diehl AJ, Bar-Eli M, Adam L: Uncoupling between epidermal growth factor receptor and downstream signals defines resistance to the antiproliferative effect of gefitinib in bladder cancer cells. Cancer Res 2005;65:10524-10535.

44 Memon AA, Sorensen BS, Meldgaard P, Fokdal L, Thykjaer T, Nexo E: The relation between survival and expression of HER1 and HER2 depends on the expression of HER3 and HER4: a study in bladder cancer patients. Br J Cancer 2006;94:1703-1709.

45 Hsu PY, Liu HS, Cheng HL, Tzai TS, Guo HR, Ho CL, Chow NH: Collaboration of RON and epidermal growth factor receptor in human bladder carcinogenesis. J Urol 2006;176: 2262-2267.

46 Choueiri TK, Vaishampayan UN, Yu EY, Quinn DI, Hahn NM, Hutson TE, Ross RW, Rosenberg JE, Jacobus SJ, Kantoff PW: A double-blind randomized trial of docetaxel plus vandetanib versus docetaxel plus placebo in platinum-pretreated advanced urothelial cancer. J Clin Oncol 2011;29(suppl 7):abstract LBA239.

47 Gakis G, Efstathiou J, Lerner SP, Cookson MS, Keegan KA, Guru KA, Shipley WU, Heidenreich A, Schoenberg MP, Sagaloswky AI, Soloway MS, Stenzl A: ICUD-EAU international consultation on bladder cancer 2012: radical cystectomy and bladder preservation for muscle-invasive urothelial carcinoma of the bladder. Eur Urol 2013;63:45-57. 